\title{
Macroalgal responses to ocean acidification depend on nutrient and light levels
}

\author{
Paula S. M. Celis-Plá ${ }^{1,2 *}$, Jason M. Hall-Spencer ${ }^{3}$, Paulo Antunes Horta ${ }^{4}$, \\ Marco Milazzo ${ }^{5}$, Nathalie Korbee ${ }^{1}$, Christopher E. Cornwall ${ }^{6,7}$ and Félix L. Figueroa ${ }^{1}$ \\ ${ }^{1}$ Department of Ecology, Faculty of Science, University of Málaga, Málaga, Spain, ${ }^{2}$ Laboratory of Botany, Faculty of \\ Pharmacy, University of Barcelona, Barcelona, Spain, ${ }^{3}$ Marine Biology and Ecology Research Centre, Plymouth University, \\ Plymouth, UK, ${ }^{4}$ Department of Botany, University Federal of Santa Catarina, Florianopolis, Brazil, ${ }^{5}$ Dipartimento di Scienze \\ della Terra e del Mare, University of Palermo, Palermo, Italy, ${ }^{6}$ Institute for Marine and Antarctic Studies, University of \\ Tasmania, Hobart, TAS, Australia, ${ }^{7}$ School of Earth and Environment and ARC Centre of Excellence for Coral Reef Studies, \\ University of Western Australia, Crawley, WA, Australia
}

\section{OPEN ACCESS}

Edited by:

Iris Eline Hendriks,

University of the Balearic Islands,

Spain

Reviewed by:

Peng Jin

King Abdullah University of Science and Technology, Saudi Arabia

Dorte Krause-Jensen

Aarhus University, Denmark

${ }^{*}$ Correspondence:

Paula S. M. Celis-Plá,

Department of Ecology, Faculty of

Science, University of Málaga,

Campus teatinos s/n, 29016 Málaga,

Spain

paulacelispla@uma.es

Specialty section:

This article was submitted to Global Change and the Future Ocean,

a section of the journal Frontiers in Marine Science

Received: 05 March 2015 Accepted: 04 May 2015

Published: 22 May 2015

Citation:

Celis-Plá PSM, Hall-Spencer JM, Horta PA, Milazzo M, Korbee N, Cornwall CE and Figueroa FL (2015)

Macroalgal responses to ocean acidification depend on nutrient and light levels. Front. Mar. Sci. 2:26. doi: 10.3389/fmars.2015.00026
Ocean acidification may benefit algae that are able to capitalize on increased carbon availability for photosynthesis, but it is expected to have adverse effects on calcified algae through dissolution. Shifts in dominance between primary producers will have knock-on effects on marine ecosystems and will likely vary regionally, depending on factors such as irradiance (light vs. shade) and nutrient levels (oligotrophic vs. eutrophic). Thus experiments are needed to evaluate interactive effects of combined stressors in the field. In this study, we investigated the physiological responses of macroalgae near a $\mathrm{CO}_{2}$ seep in oligotrophic waters off Vulcano (Italy). The algae were incubated in situ at $0.2 \mathrm{~m}$ depth using a combination of three mean $\mathrm{CO}_{2}$ levels (500, 700-800 and $1200 \mu \mathrm{atm}$ $\mathrm{CO}_{2}$ ), two light levels (100 and $70 \%$ of surface irradiance) and two nutrient levels of $\mathrm{N}, \mathrm{P}$, and $\mathrm{K}$ (enriched vs. non-enriched treatments) in the non-calcified macroalga Cystoseira compressa (Phaeophyceae, Fucales) and calcified Padina pavonica (Phaeophyceae, Dictyotales). A suite of biochemical assays and in vivo chlorophyll a fluorescence parameters showed that elevated $\mathrm{CO}_{2}$ levels benefitted both of these algae, although their responses varied depending on light and nutrient availability. In C. compressa, elevated $\mathrm{CO}_{2}$ treatments resulted in higher carbon content and antioxidant activity in shaded conditions both with and without nutrient enrichment-they had more Chla, phenols and fucoxanthin with nutrient enrichment and higher quantum yield $\left(F_{v} / F_{m}\right)$ and photosynthetic efficiency $\left(\alpha_{\mathrm{ETR}}\right)$ without nutrient enrichment. In $P$. pavonica, elevated $\mathrm{CO}_{2}$ treatments had higher carbon content, $F_{v} / F_{m}, \alpha_{\mathrm{ETR}}$, and Chla regardless of nutrient levels - they had higher concentrations of phenolic compounds in nutrient enriched, fully-lit conditions and more antioxidants in shaded, nutrient enriched conditions. Nitrogen content increased significantly in fertilized treatments, confirming that these algae were nutrient limited in this oligotrophic part of the Mediterranean. Our findings strengthen evidence that brown algae can be expected to proliferate as the oceans acidify where physicochemical conditions, such as nutrient levels and light, permit.

Keywords: ocean acidification, macroalgae, photosynthesis, phenolic compounds, nutrient availability 


\section{Introduction}

Ocean acidification due to increased atmospheric $\mathrm{CO}_{2}$ levels is altering the concentrations of dissolved inorganic carbon (DIC) in surface waters; $\mathrm{CO}_{3}^{2-}$ levels are falling, which is expected to corrode marine carbonates, whilst $\mathrm{CO}_{2}$ and $\mathrm{HCO}_{3}^{-}$levels are rising which can stimulate photosynthesis (Connell et al., 2013; Cornwall et al., 2015). As some primary producers are better able to capitalize on increasing carbon availability than others, this is expected to alter marine communities (Hepburn et al., 2011; Connell et al., 2013; Koch et al., 2013; Gaylord et al., 2015). In the Mediterranean, surveys of coastal $\mathrm{CO}_{2}$ seeps have repeatedly shown that coralline algae and sea urchins become less common as $\mathrm{pH}$ and $\mathrm{CO}_{3}^{2-}$ fall, whereas brown algae, such as Cystoseira spp., Dictyota spp., Sargassum vulgare and Padina pavonica, proliferate as $\mathrm{CO}_{2}$ and $\mathrm{HCO}_{3}^{-}$levels rise (Porzio et al., 2011; Baggini et al., 2014). The ways in which ocean acidification affects communities of primary producers are likely to vary regionally, depending on the species present and abiotic factors such as temperature, light and nutrient availability (Giordano et al., 2005; Brodie et al., 2014; Hofmann et al., 2014).

To begin to understand the influence of physicochemical factors on the responses of macroalgae to ocean acidification, we grew common types of brown algae (from the Families Fucales and Dictyotales) at $\mathrm{CO}_{2}$ seeps in a multifactorial experiment in which we manipulated light (irradiance) and nutrient levels. At low light levels, macroalgae are thought to be more likely to rely on carbon uptake via diffusion than use energetically expensive carbon concentrating mechanisms (Raven and Beardall, 2014; Raven et al., 2014) which has led to the idea that any benefits of ocean acidification on growth would only be seen at lower light levels for the majority of species (Hepburn et al., 2011). However, ocean acidification also has the potential to damage photoprotective mechanisms which kick-in at high light levels (Pierangelini et al., 2014). Algae minimize damage from high irradiance by down-regulating photosystemsthey also produce chemicals, such as phenolic compounds in the brown algae, which screen ultraviolet light and dissipate energy (Figueroa et al., 2014a). In oligotrophic waters, such as those of the Mediterranean, nutrient availability generally limits macroalgal growth (Ferreira et al., 2011), photosynthetic capacity (Pérez-Lloréns et al., 1996) and photoprotective mechanisms (Celis-Plá et al., 2014a).

Our study centers upon a highly oligotrophic region (the Tyrrhenian Sea) which is undergoing rapid changes in carbonate chemistry coupled with coastal eutrophication and increased land run-off (Oviedo et al., 2015). In this region, as with elsewhere in the world, canopy-forming brown algae have undergone a decline in abundance due to anthropogenic perturbation (Scherner et al., 2013; Strain et al., 2014; Yesson et al., 2015). Here, we investigate the interactive effects of increasing $\mathrm{CO}_{2}$ levels and eutrophication on Cystoseira compressa and Padina pavonica using a $\mathrm{pH}$ gradient caused by volcanic seeps. These species were chosen because they are abundant around shallow Mediterranean $\mathrm{CO}_{2}$ seeps (Baggini et al., 2014), because Cystoseira spp. are indicators of high water quality in the Mediterranean (Bermejo et al., 2013) and since
Padina spp. tolerate loss of external calcification as $\mathrm{CO}_{2}$ levels increase (Johnson et al., 2012; Pettit et al., 2015).

Macroalgal responses to ocean acidification may well depend upon their nutrient metabolism, which can vary widely between species (Hofmann et al., 2014; Hurd et al., 2014). Here, we compared interspecific physiological and biochemical responses to ocean acidification under different light and nutrient levels using standard methods for the study of multiple physical stressors in algae (Martínez et al., 2012; Celis-Plá et al., 2014a). Our hypothesis was that both brown algal species would benefit from ocean acidification in shaded conditions when nutrient levels were elevated. We expected that high light levels would inhibit photosystems, and that any benefits from high $\mathrm{CO}_{2}$ would only occur if sufficient nutrients were available. If this were true we expected to observe increased photosynthetic activity (using electron transport rates and carbon content as a proxy) and increases in phenolic and antioxidant production in shaded nutrient-enriched treatments.

\section{Materials and Methods}

\section{Experimental Design}

Macroalgal incubations took place from 19 to 22 March 2013, along a $\mathrm{CO}_{2}$ gradient near Vulcano, Italy (Figure 1; Boatta et al., 2013). Cystoseira compressa and Padina pavonica were collected at $0.5 \mathrm{~m}$ depth from a reference zone. Thalli ( $5 \mathrm{~g}$ fresh weight) were held in individual mesh cylinders $(15 \mathrm{~cm}$ long $\times 5 \mathrm{~cm}$ in diameter) set $1 \mathrm{~m}$ apart and suspended at $0.2 \mathrm{~m}$ depth off a floating line that was anchored to the seabed perpendicular to the coast. This array was replicated at an ambient $\mathrm{CO}_{2}$ site $(c a$ $500 \mu$ atm $\left.\mathrm{CO}_{2}\right)$, a medium $\mathrm{CO}_{2}$ site (ca 700-800 $\mu$ atm $\left.\mathrm{CO}_{2}\right)$ and a high $\mathrm{CO}_{2}$ site ( $c a 1200 \mu$ atm $\mathrm{CO}_{2}$ ) (Table 1).

Each $\mathrm{CO}_{2}$ zone had 12 replicates per treatment per species (nutrient enriched + ambient light or $100 \%$ PAB, i.e., $100 \%$ of surface irradiance defined as PAB irradiance (PAR + UVR), nutrient enriched + shaded light or $70 \%$ PAB , i.e., $70 \%$ of surface irradiance defined as $\mathrm{PAB}$ irradiance (PAR + UVR), nonenriched + ambient light or $100 \%{ }_{\mathrm{PAB}}$, non-enriched shaded light

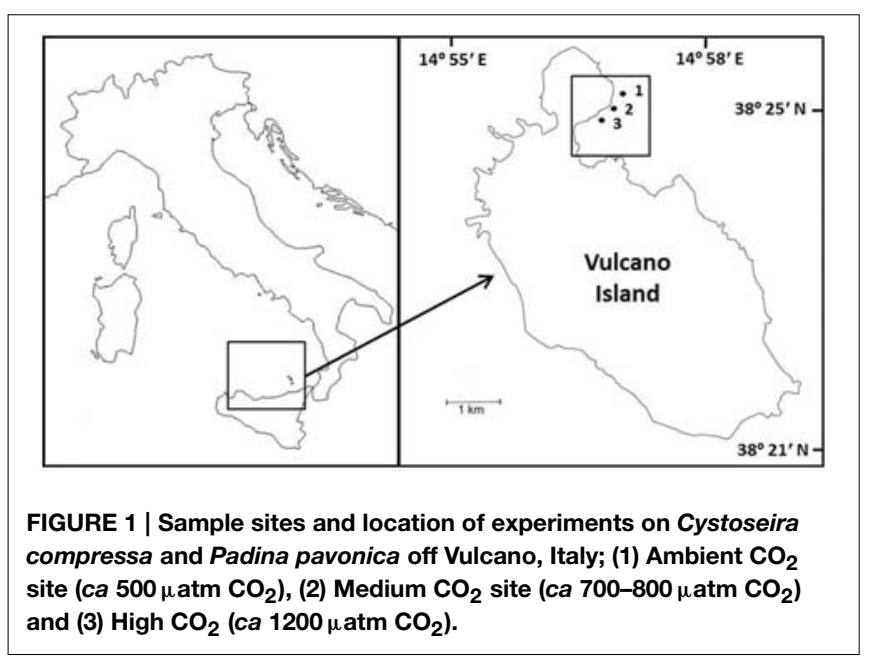


TABLE 1 | Seawater carbonate chemistry at three sites off Vulcano Island.

\begin{tabular}{lccc}
\hline & Ambient $\mathbf{C O}_{\mathbf{2}}$ & ${\text { Medium } \mathbf{C O}_{\mathbf{2}}}$ & ${\text { High } \mathbf{C O}_{\mathbf{2}}}$ \\
\hline Salinity & $38.19 \pm 0.03$ & $38.21 \pm 0.04$ & $38.23 \pm 0.04$ \\
Temperature $\left({ }^{\circ} \mathrm{C}\right)$ & $14.94 \pm 0.21$ & $14.99 \pm 0.13$ & $15.06 \pm 0.19$ \\
$\mathrm{pH}_{\mathrm{NBS}}$ & $8.11 \pm 0.02$ & $7.97 \pm 0.04$ & $7.86 \pm 0.09$ \\
$\mathrm{pCO}_{2}(\mu \mathrm{atm})$ & $512 \pm 29$ & $779 \pm 109$ & $1250 \pm 410$ \\
$\mathrm{CO}_{2}\left(\mu \mathrm{mol} \mathrm{kg}{ }^{-1}\right)$ & $18.8 \pm 1.2$ & $28.7 \pm 4.1$ & $46 \pm 15.3$ \\
$\mathrm{HCO}_{3}^{-}\left(\mu \mathrm{mol} \mathrm{kg}{ }^{-1}\right)$ & $2129 \pm 20$ & $2161 \pm 23$ & $2236 \pm 36$ \\
$\mathrm{CO}_{3}^{2-}\left(\mu \mathrm{mol} \mathrm{kg}{ }^{-1}\right)$ & $181 \pm 8.3$ & $138 \pm 9.3$ & $119 \pm 14.6$ \\
Total Alkalinity $\left(\mu \mathrm{mol} \mathrm{kg}{ }^{-1}\right)$ & $2527 \pm 46$ & $2499 \pm 14$ & $2569 \pm 427$ \\
$\Omega$ Calcite & $4.21 \pm 0.19$ & $3.22 \pm 0.22$ & $2.78 \pm 0.34$ \\
$\Omega$ Aragonite & $2.71 \pm 0.13$ & $2.07 \pm 0.14$ & $1.79 \pm 0.22$
\end{tabular}

Island, with an ambient $\mathrm{CO}_{2}$, a Medium $\mathrm{CO}_{2}$ and a High $\mathrm{CO}_{2}$ site. Temperature $\left({ }^{\circ} \mathrm{C}\right.$ ), Salinity and pH (NBS scale) were collected on different days in March 2013 (mean values $\pm S E, n=5-14)$. Average total alkalinity $\left(\mu \mathrm{mol} \mathrm{kg}{ }^{-1}\right)$ was calculated from water samples collected at each site on 20th March 2013 (mean values \pm SE, $n=3$ ).

or $70 \%$ PAB $)$. Light levels were manipulated using a $1 \mathrm{~mm}^{2}$ size pore mesh that reduced light levels to $70 \%$ of that of the unshaded treatments. The filter we used does not modify the light spectra (Aphalo et al., 2013). Mesh bags containing $100 \mathrm{~g}$ of a slowrelease fertilizer comprising $17 \% \mathrm{~N}\left(\mathrm{NH}_{4}^{+}\right.$and $\left.\mathrm{NO}_{3}^{-}\right), 17 \% \mathrm{P}$ $\left(\mathrm{P}_{2} \mathrm{O}_{5}\right)$ and $17 \% \mathrm{~K}$ (Multicote ${ }^{\circledR}$, Haifa Chemicals, USA) were attached below nutrient enriched cylinders. For the non-enriched treatments, a bag with $100 \mathrm{~g}$ of sand was used as a control. The nutrient treatments were set $20 \mathrm{~m}$ apart from each other so that non-enriched treatments were unaffected.

\section{Environmental Conditions}

The seawater carbonate system was monitored at each site (Table 1). A 556 MPS YSI (Yellow Springs, USA) probe was used to measure salinity, $\mathrm{pH}$ and temperature $\left({ }^{\circ} \mathrm{C}\right)$. The $\mathrm{pH}$ sensor was calibrated using NBS scale standard buffers. On 20th March 2013, water samples for total alkalinity (TA) were strained through $0.2 \mu \mathrm{m}$ filters, poisoned with $0.05 \mathrm{ml}$ of $50 \% \mathrm{HgCl}_{2}$, and then stored in the dark at $4{ }^{\circ} \mathrm{C}$. Three replicates were analyzed at $25^{\circ} \mathrm{C}$ using a titrator (Mettler Toledo, Inc.). The $\mathrm{pH}$ was measured at $0.02 \mathrm{ml}$ increments of $0.1 \mathrm{~N} \mathrm{HCl}$.

Total alkalinity was calculated from the Gran function applied to $\mathrm{pH}$ variations from 4.2 to 3.0 , from the slope of the curve $\mathrm{HCl}$ volume vs. $\mathrm{pH}$. The $\mathrm{pCO}_{2}$ and the saturation state of aragonite were calculated from $\mathrm{pH}_{\mathrm{NBS}}$, $\mathrm{TA}$, temperature and salinity using the $\mathrm{CO}_{2}$ SYS package (Pierrot and Wallace, 2006), using the constants of Roy et al. (1993) and Dickson (1990). Saturation state $(\Omega)$ is the ion product of calcium and carbonate ion concentrations as:

$$
\Omega=\left[\mathrm{Ca}^{2+}\right]\left[\mathrm{CO}_{3}^{2-}\right] / K^{\prime} s p
$$

The apparent solubility product K'sp depends on temperature, salinity, pressure, and the particular mineral phase (e.g. calcite and aragonite in this case).

Irradiance was monitored at the sea surface at two wavelength bands using PAR (QSO-SUN 2.5V) and UV-A (USB-SU 100, Onset Computer Corporation, Massachusetts, USA) sensors sealed in a water proof box (OtterBox3000). Water temperature was monitored using a HOBO logger (Onset Computer Corporation, Massachusetts, USA). The nutrient enrichment caused by the release of the fertilizer was assessed taking triplicate seawater samples at both enriched and non-enriched sites. Seawater was strained using portable GF/F filters (Whatman International. Ltd., Maidstone, UK) then transported to the laboratory inside an isotherm bag $\left(4^{\circ} \mathrm{C}\right.$, in darkness), and kept at $-20^{\circ} \mathrm{C}$. Nitrate $\left(\mathrm{NO}_{3}^{-}\right)$was determined using an automated analyzer (SanPlus ${ }^{++}$System, SKALAR, Breda, Netherlands) applying standard colorimetric procedures (Koroleff, 1983).

\section{Physiological and Biochemical Variables}

Several physiological variables were obtained from the algae within each cylinder at the end of the experiment. These variables were also measured in C. compressa and $P$. pavonica from ambient $\mathrm{CO}_{2}$ site $(500 \mu \mathrm{atm})$ populations at $0.5 \mathrm{~m}$ depth. Carbon and nitrogen contents were determined using an element analyzer CNHS-932 model (LECO Corporation, Michigan, USA).

In vivo chlorophyll a fluorescence associated with Photosystem II was determined by using a portable pulse amplitude modulated (PAM) fluorometer (Diving-PAM, Walz $\mathrm{GmbH}$, Germany). Macroalgal thalli were collected from natural populations (initial time) and after 4 days of incubation in the experiment (for each treatment or cylinder), and were put in $10 \mathrm{~mL}$ incubation chambers to obtain rapid light curves for each treatment. $F_{\mathrm{o}}$ and $F_{\mathrm{m}}$ were measured after $15 \mathrm{~min}$ in darkness to obtain the maximum quantum yield $\left(F_{\mathrm{V}} / F_{\mathrm{m}}\right)$ being $F_{\mathrm{v}}=F_{\mathrm{m}}-F_{\mathrm{o}}, F_{\mathrm{o}}$ the basal fluorescence of $15 \mathrm{~min}$ dark adapted thalli and $F_{\mathrm{m}}$ maximal fluorescence after a saturation light pulse of $>4000 \mu \mathrm{mol} \mathrm{m} \mathrm{m}^{-2} \mathrm{~s}^{-1}$ (Schreiber et al., 1995). The electron transport rate (ETR) was determined after $20 \mathrm{~s}$ exposure in eight increasing irradiances of white light (halogen lamp provided by the Diving-PAM). The ETR was calculated according to Schreiber et al. (1995) as follows:

$$
\text { ETR }\left(\mu \text { mol electrons } m^{-2} s^{-1}\right)=\Delta F / F_{m}^{\prime} \times E \times A \times F_{I I}
$$

where $\Delta F / F_{m}^{\prime}$ is the effective quantum yield, being $\Delta F=F m^{\prime}-F t$ ( $F t$ is the intrinsic fluorescence of alga incubated in light and $\mathrm{Fm}^{\prime}$ is the maximal fluorescence reached after a saturation pulse of algae incubated in light), $E$ is the incident PAR irradiance expressed in $\mu \mathrm{mol}$ photons $\mathrm{m}^{-2} \mathrm{~s}^{-1}, \mathrm{~A}$ is the thallus absorptance as the fraction of incident irradiance that is absorbed by the algae (see Figueroa et al., 2003) and $\mathrm{F}_{\mathrm{II}}$ is the fraction of chlorophyll related to PSII $(400-700 \mathrm{~nm})$ being 0.8 in brown macroalgae (Figueroa et al., 2014a). ETR parameters as maximum electron transport rate $\left(\mathrm{ETR}_{\max }\right)$ and the initial slope of ETR vs. irradiance function $\left(\alpha_{\mathrm{ETR}}\right)$ as estimator of photosynthetic efficiency were obtained from the tangential function reported by Eilers and Peeters (1988). Finally, the saturation irradiance for ETR (Ek $\left.k_{\mathrm{ETR}}\right)$ was calculated from the intercept between $\mathrm{ETR}_{\max }$ and $\alpha_{\mathrm{ETR}}$. Non-photochemical quenching (NPQ) was calculated according to Schreiber et al. (1995) as:

$$
N P Q=\left(F_{m}-F_{m}^{\prime}\right) / F_{m}^{\prime}
$$

Maximal NPQ (NPQ $\mathrm{Nax}_{\max }$ ) and the initial slope of NPQ vs. irradiance function $\left(\alpha_{\mathrm{NPQ}}\right)$ were obtained from the tangential 
function of NPQ vs. irradiance function according to Eilers and Peeters (1988).

Pigments were extracted from $20 \mathrm{mg}$ fresh weight of thalli using $2 \mathrm{~mL}$ of $100 \%$ acetone and analyzed using an ultrahigh-performance liquid chromatographer (Shimadzu Corp., Kyoto, Japan) equipped with a photodiode array detector to measure peaks in the range $350-800 \mathrm{~nm}$. After extraction samples were centrifuged at $16200 \mathrm{~g}$ for $5 \mathrm{~min}$ (Sorvall Legend Micro 17, Thermo Scientific, Langenselbold, Germany) and then the extracts were filtered $(0.22 \mu \mathrm{m}$ nylon filters). The separation, was achieved with one column C-18 reversed phase (Shim-pack XRODS column; $3.0 \times 75 \mathrm{~mm}$ i. d.; $2.2 \mu \mathrm{m}$ particle size; Shimadzu, Kyoto, Japan) protected by a guard column TR-C-160 K1 (Teknokroma, Barcelona, Spain). The carotenoid composition was determined according to García-Plazaola and Becerril (1999) with some modifications (García-Plazaola et al., 2012), using commercial standards (DHI LAB Products). The mobile phase consisted of two components: Solvent A, acetonitrile: methanol: Tris buffer (0.1 M, pH 8) (84:2:14); and solvent B, methanol: ethyl acetate (68:32). The pigments were eluted using a linear gradient from $100 \%$ A to $100 \%$ B for the first $7 \mathrm{~min}$, followed by an isocratic elution with $100 \% \mathrm{~B}$ for the next $4 \mathrm{~min}$. This was followed by a $50 \mathrm{~s}$ linear gradient from $100 \%$ B to $100 \% \mathrm{~A}$ and an isocratic elution with $100 \% \mathrm{~B}$ for the next 3 min to allow the column to re-equilibrate with solvent $\mathrm{A}$, prior to the next injection.

Total phenolic compounds were determined using $0.25 \mathrm{~g}$ fresh weight samples pulverized with a mortar and pestle with sand and $2.5 \mathrm{~mL}$ of $80 \%$ methanol. After keeping the samples overnight at $4^{\circ} \mathrm{C}$, the mixture was centrifuged at $2253 \mathrm{~g}$ for $30 \mathrm{~min}$ at $4^{\circ} \mathrm{C}$, and then the supernatant was collected. Total phenolic compounds were determined colorimetrically using Folin-Ciocalteu reagent and phloroglucinol (1,3,5-trihydroxybenzene, Sigma P-3502) as standard. Finally the absorbance was determined at $760 \mathrm{~nm}$ using a spectrophotometer (UV Mini-1240, Shimadzu) (Celis-Plá et al., 2014b). Total phenolic content was expressed as $\mathrm{mg} \mathrm{g}^{-1}$ DW after determining the fresh to dry weight ratio in the tissue (5.2 for C. compressa and 4.5 P. pavonica, respectively). The results are expressed as average \pm SE from three replicates of each treatment. Antioxidant activity was measured on polyphenol extracts according to Blois (1958); $150 \mu \mathrm{L}$ of DPPH (2,2-diphenyl-1-picrylhydrazyil) prepared in $90 \%$ methanol were added to each extract. The reaction was complete after $30 \mathrm{~min}$ in darkness at ambient temperature $\left(\sim 20^{\circ}\right)$, and the absorbance was read at $517 \mathrm{~nm}$ in a spectrophotometer (UVmini-1240, Shimadzu). The calibration curve made from $\mathrm{DPPH}$ was used to calculate the remaining concentration of $\mathrm{DPPH}$ in the reaction mixture after incubation. Values of DPPH concentration $(\mathrm{mM})$ were plotted against plant extract concentration expressed as the $\mathrm{EC}_{50}$ value (oxidation index, $\mathrm{mg}$ $\mathrm{DW} \mathrm{mL} \mathrm{m}^{-1}$ ) required to scavenge $50 \%$ of the $\mathrm{DPPH}$ in the reaction mixture. Ascorbic acid was used as a control (Celis-Plá et al., 2014b).

\section{Statistical Analysis}

The effects of the in situ treatments on the physiological responses of $C$. compressa and $P$. pavonica were assessed using analysis of variance. Three fixed factors were considered: Site with three levels: ambient $\mathrm{CO}_{2}$ site, medium $\mathrm{CO}_{2}$ and high $\mathrm{CO}_{2}$, Irradiance with two levels: 70 and $100 \%$ of surface irradiance (PAR + UVR irradiance), and two nutrient levels; enriched $(\mathrm{N}+)$ and non-enriched $(\mathrm{N})$. This design allowed us to test interactive and additive effects of the variables on physiological responses after the 4 day experimental period. Student Newman Keuls tests (SNK) were performed on significant ANOVA interactions. Homogeneity of variance was tested using Cochran tests and by visual inspection of the residuals. All data conformed to homogeneity of variance. Analyses were performed by using SPSS v.21 (IBM, USA).

\section{Results}

\section{Environmental Conditions}

Cystoseira compressa and Padina pavonica were abundant at all three stations; $P$. pavonica was visibly less calcified at the site with the highest levels of $\mathrm{CO}_{2}$. The seawater temperature was about $15^{\circ} \mathrm{C}$ and the salinity was 38 at all stations; at the Ambient site, mean $\mathrm{pH}$ was 8.11 , at the Medium $\mathrm{CO}_{2}$ site (700-800 $\left.\mu \mathrm{atm}\right)$, mean $\mathrm{pH}$ was 7.97 and at the High $\mathrm{CO}_{2}$ site (1200 $\mu$ atm), it was 7.86 (Table 1).

The average daily irradiance for the experimental period was $5360 \mathrm{~kJ} \mathrm{~m}^{-2}$ for PAR and $666 \mathrm{~kJ} \mathrm{~m}^{-2}$ for UVA. The nutrient enriched treatments had approximately 100 times the nitrate concentration of the ambient seawater; ambient vs. enriched ratios were $0.16 \pm 0.04$ vs. $106.17 \pm 9.37 \mu \mathrm{M}$ for the ambient site, $0.13 \pm 0.01$ vs. $106.33 \pm 9.37 \mu \mathrm{M}$ at the medium $\mathrm{CO}_{2}$ site and $0.25 \mu \mathrm{M} \pm 0.01$ vs. $106.42 \pm 9.37 \mu \mathrm{M}$ at the high $\mathrm{CO}_{2}$ site (mean $\pm \mathrm{SE}, n=3$ ).

\section{Physiological and Biochemical Responses}

The carbon content of $C$. compressa increased with increasing $\mathrm{CO}_{2}$, whereas in $P$. pavonica showed interactive effects between all factors. Carbon, in $P$. pavonica showed maximal values $279.9 \pm 6.5$ with increased $\mathrm{CO}_{2}$, in non-enrichment enriched treatments and minimal values $225.3 \pm 2.4 \mathrm{mg} \mathrm{g}^{-1}$ DW with decreased $\mathrm{CO}_{2}$, non-nutrient enriched and $70 \% \mathrm{PAB}$ conditions (Table 2, Table S1). The nitrogen content of $C$. compressa was greatest in the high $\mathrm{CO}_{2}$, nutrient enriched and $70 \% \mathrm{PAB}$ treatment (Figure 2A, Figure S1); conversely, in $P$. pavonica the nitrogen content was highest at the reference site, ambient $\mathrm{CO}_{2}$ treatment (Figure 2B, Figure $\mathrm{S} 1$ ). The ratio C:N of C. compressa did not show significant differences between treatments (Figure 3A, Figure S1), whereas the ratio in $P$. pavonica showed significant effects for $\mathrm{CO}_{2}$ levels and nutrient enrichment showed maximal values (19.5 \pm 5.8) with increased $\mathrm{CO}_{2}$, non-nutrient enriched in $100 \% \mathrm{PAB}$ conditions and minimal values $15.9 \pm 0.5$ in medium $\mathrm{CO}_{2}$, nutrient enrichment and 70\% Figure S1).

The maximal quantum yield $\left(F_{v} / F_{m}\right)$ was significantly different between $\mathrm{CO}_{2}$ treatments, nutrient and irradiance in both macroalgae (Figure 4, Figure S2). In C. compressa, the $F_{v} / F_{m}$ was greatest in $70 \%$ РAB treatments with high $\mathrm{CO}_{2}$, and nonenriched enrichment (Figure 4A, Figure S2), but in P. pavonica 


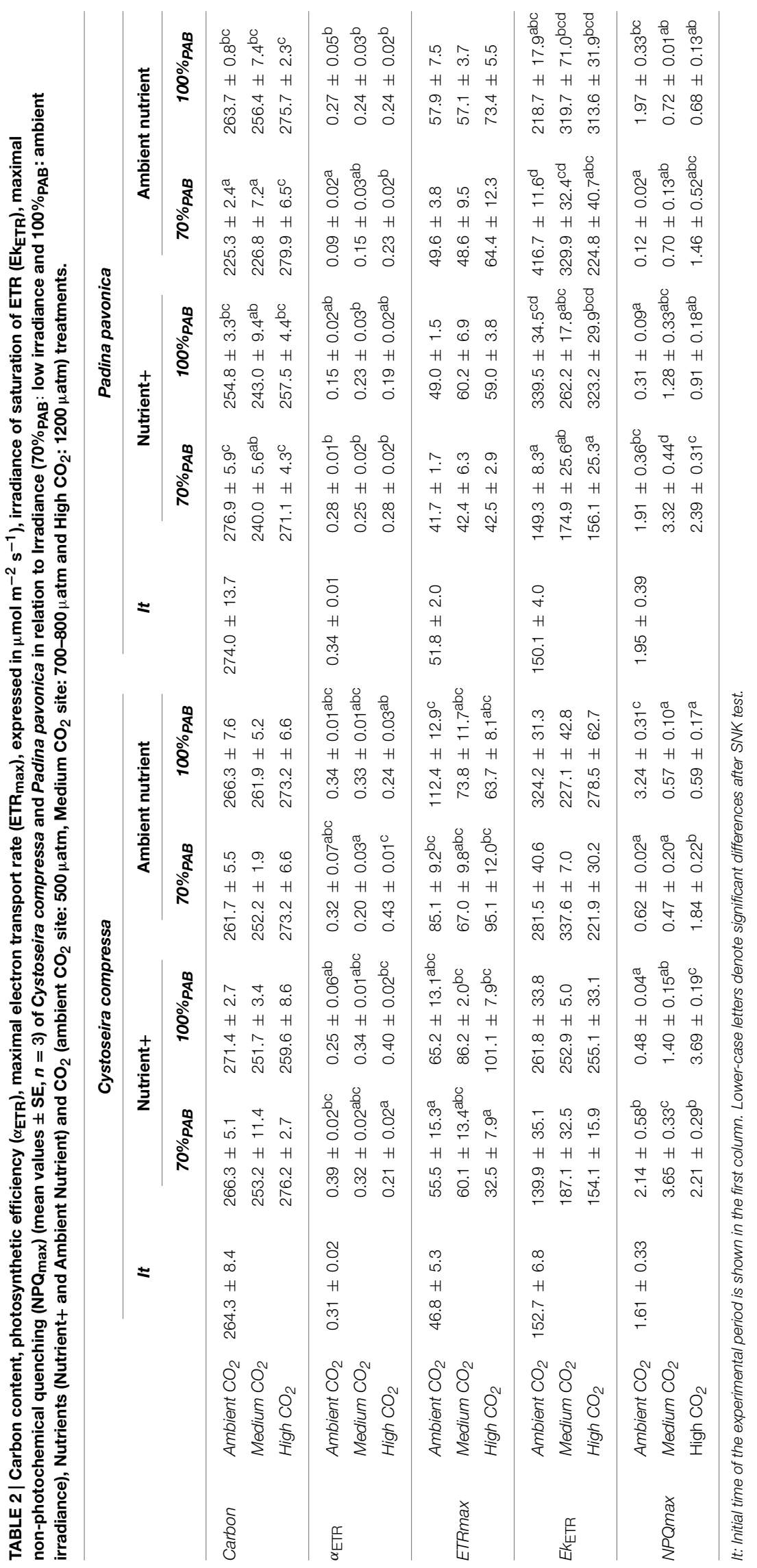




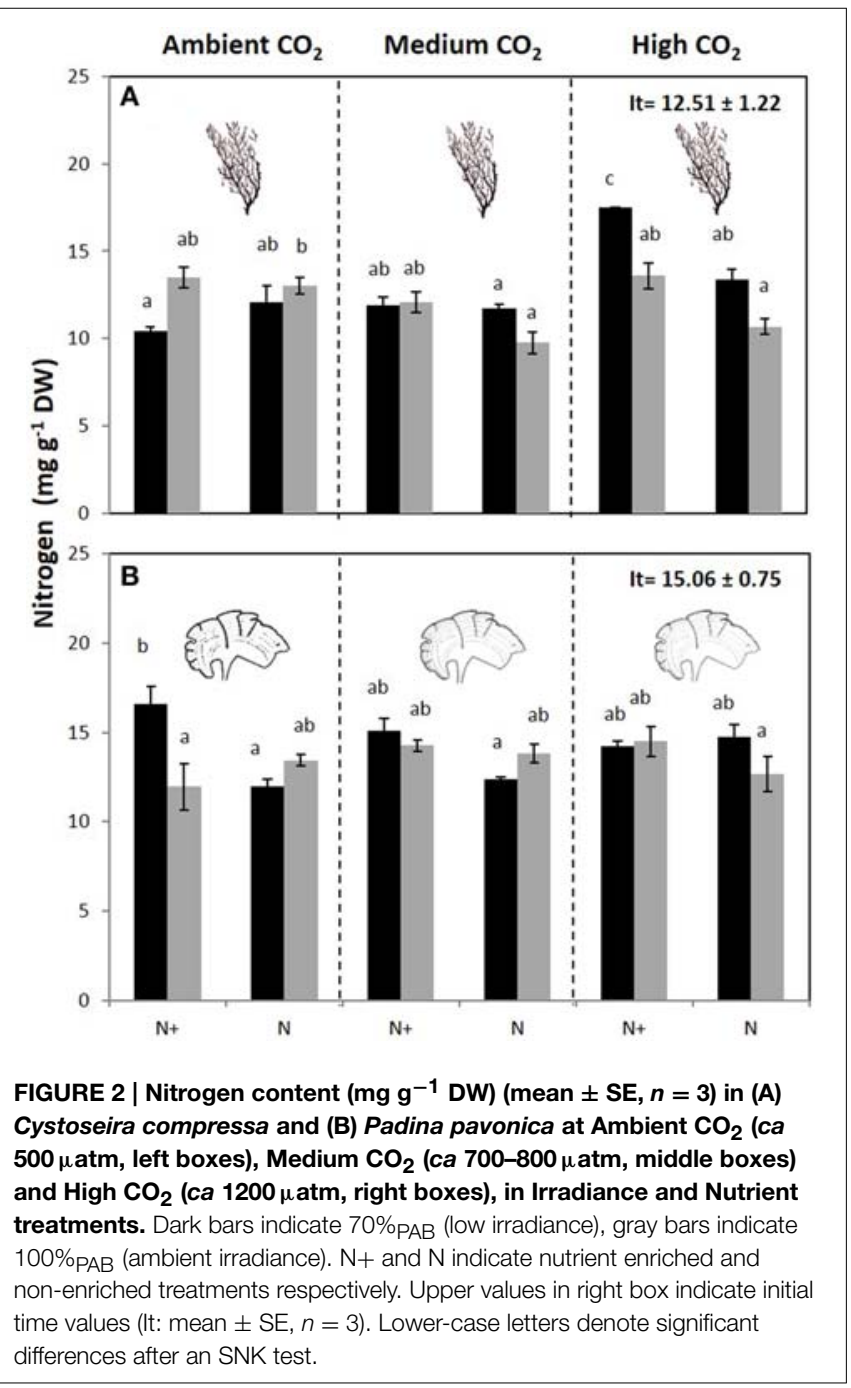

this was greatest in the nutrient enriched treatments (Figure 4B, Figure S2). The $\alpha_{\mathrm{ETR}}$ values also varied significantly between treatments in both species (Table 2, Table S2). In C. compressa, $\alpha_{\mathrm{ETR}}$ was greatest in $70 \%$ PAB treatments at high $\mathrm{CO}_{2}$ with nonenriched enrichment; in $P$. pavonica $\alpha_{\mathrm{ETR}}$ was greatest in the high $\mathrm{CO}_{2}$ conditions (Table 2, Table S2). ETR $\mathrm{max}_{\text {in }}$ C. compressa was highest in high $\mathrm{CO}_{2}, 70 \%$ РАB and non-nutrient enrichment, also in $100 \% \mathrm{PAB}$ and nutrient enrichment, and also this was higher with decreased $\mathrm{CO}_{2}, 100 \% \mathrm{PAB}$, in non-nutrient enrichment. In $P$.

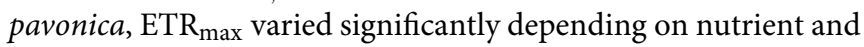
irradiance, without interactions (Table 2, Table S2). In contrast, the $\mathrm{Ek}_{\mathrm{ETR}}$ in C. compressa had one significant interaction among nutrient $\mathrm{x}$ irradiance. $P$. pavonica had significant interactions between $\mathrm{CO}_{2}$ level, nutrient and irradiance. The $\mathrm{Ek}_{\mathrm{ETR}}$, in $C$. compressa, was greatest in the $100 \%{ }_{\mathrm{PAB}}$ treatments that had no $\mathrm{CO}_{2}$ or nutrient enrichment, but in $P$. pavonica $\mathrm{Ek}_{\mathrm{ETR}}$ was greatest in 70\% РАв conditions (Table 2, Table S2). In both species, the maximal non-photochemical quenching $\left(\mathrm{NPQ}_{\max }\right)$ was affected by the interaction of all factors. In C. compressa, $\mathrm{NPQ}_{\max }$ increased significantly with increasing $\mathrm{CO}_{2}$ conditions,

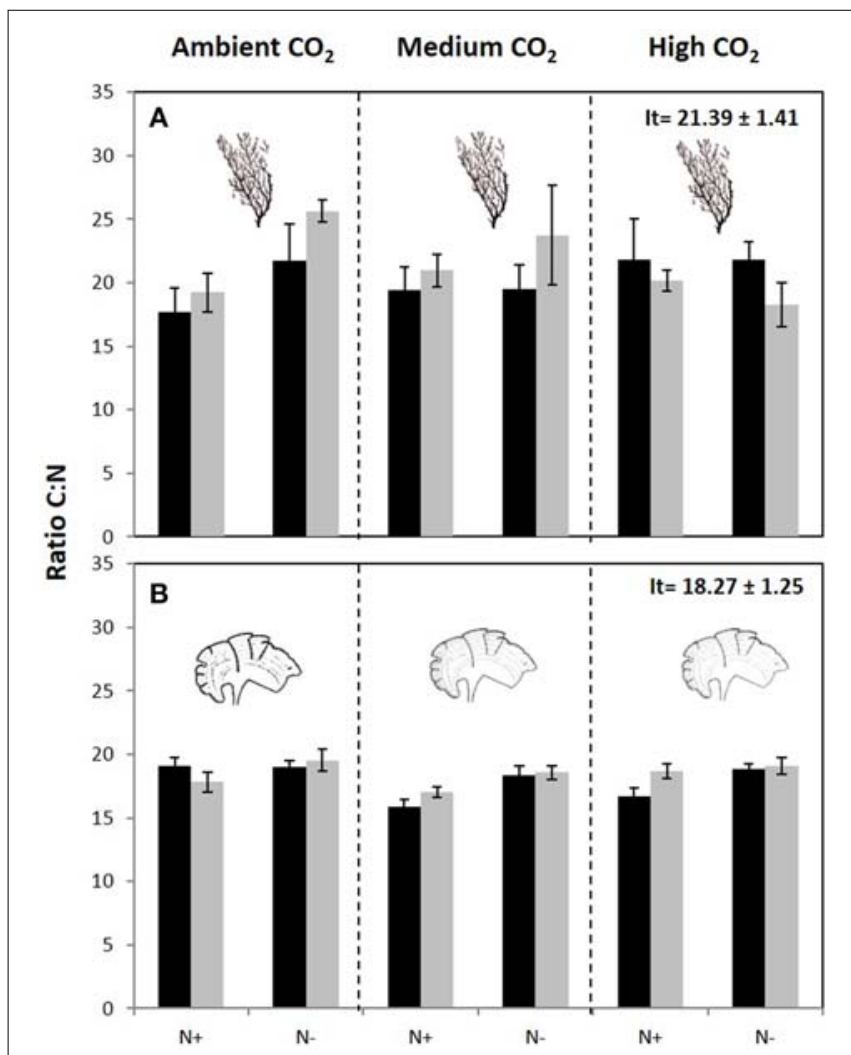

FIGURE 3 | C:N ratio (mean $\pm \mathrm{SE}, n=3$ ) in (A) Cystoseira compressa and (B) Padina pavonica at Ambient $\mathrm{CO}_{2}$ (ca $500 \mu \mathrm{atm}$, left boxes), Medium $\mathrm{CO}_{2}$ (ca 700-800 $\mu \mathrm{atm}$, middle boxes) and $\mathrm{High}^{\mathrm{CO}} \mathrm{CO}_{2}$ (ca $1200 \mu \mathrm{atm}$, right boxes), in Irradiance and Nutrient treatments. Dark bars indicate 70\% irradiance). $\mathrm{N}+$ and $\mathrm{N}$ indicate nutrient enriched and non-enriched treatments respectively. Upper values in right box indicate initial time values (It: mean \pm $\mathrm{SE}, n=3)$.

under nutrient enriched and $100 \%_{\mathrm{PAB}}$, also increased in ca $700-$ $800 \mu \mathrm{atm}$ but in $70 \% \mathrm{PAB}$. As well as, $\mathrm{NPQ}_{\max }$ increased under ambient $\mathrm{CO}_{2}$ conditions in $100 \%$ PAB in nutrient non-enriched. Finally, in $P$. pavonica, the $\mathrm{NPQ}_{\max }$ was significantly higher in $70 \%$ PAB at $700 \mu \mathrm{atm} \mathrm{CO}_{2}$ treatment with nutrient enrichment (Table 2, Table S2).

Nutrient enrichment increased Chla significantly in $C$. compressa. In contrast, in $P$. pavonica significant differences were found for the following interactions: $\mathrm{CO}_{2}$ level $\times$ nutrient, $\mathrm{CO}_{2}$ level $\times$ irradiance and nutrient $\times$ irradiance (Table 3, Table S3). The same occurred for Chlc in $P$. pavonica; but there was no significant difference in C. compressa (Table 3, Table S3). The carotenoids, fucoxanthin and violaxanthin in C. compressa did not differ among factors (Table 3, Table S3) but in P. pavonica the fucoxanthin and violaxanthin contents were affected by the interaction of all factors. Fucoxanthin increased in 70\%pAB, nonenriched treatments in ambient $\mathrm{CO}_{2}$ whereas violoxanthin levels were highest in 70\% $\mathrm{PAB}, \mathrm{ca} 700-800 \mu \mathrm{atm} \mathrm{CO}_{2}$, nutrient enriched treatment (Table 3, Table S3).

Phenolic content (PC) was affected by the interaction of all factors in both species (Figure 5, Figure S4). In C. compressa, PC 


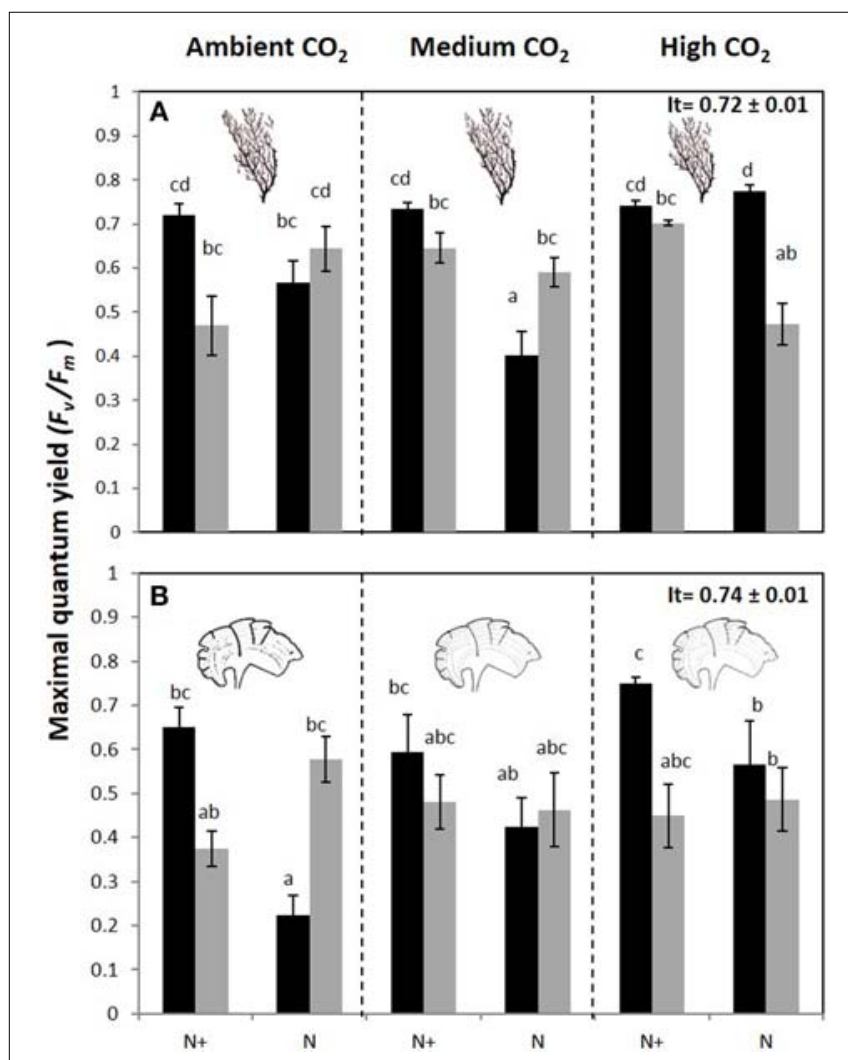

FIGURE 4 | Maximal quantum yield or $F_{V} / F_{m}$ (mean $\pm S E, n=3$ ) in (A) Cystoseira compressa and (B) Padina pavonica at Ambient $\mathrm{CO}_{2}$ (ca $500 \mu \mathrm{atm}$, left boxes), Medium $\mathrm{CO}_{2}$ (ca 700-800 $\mu \mathrm{atm}$, middle boxes) and $\mathrm{High} \mathrm{CO}_{2}$ (ca $1200 \mu \mathrm{atm}$, right boxes), in Irradiance and Nutrient treatments. Dark bars indicate 70\% indicate 100\% and non-enriched treatments respectively. Upper values in right box indicate initial time values (It: mean $\pm \mathrm{SE}, n=3$ ). Lower-case letters denote significant differences after an SNK test.

was highest in $\mathrm{CO}_{2}$ and nutrient enriched conditions (Figure $\mathbf{5 A}$, Figure S4). In P. pavonica at $1200 \mu \mathrm{atm} \mathrm{CO}_{2}, \mathrm{PC}$ was high in $100 \% \mathrm{PAB}$ and nutrient enriched treatments and in $70 \% \mathrm{PAB}$ treatments non-nutrient enrichment (Figure 5B, Figure S4). Antioxidant activity $\left(\mathrm{EC}_{50}\right)$ showed a significant interaction between $\mathrm{CO}_{2}$ level $\times$ nutrient and $\mathrm{CO}_{2}$ level $\times$ irradiance in C. compressa; however in $P$. pavonica the only significant difference found in antioxidant activity was between $\mathrm{CO}_{2}$ level and irradiance. In C. compressa and P. pavonica, $\mathrm{EC}_{50}$ was lowest (i.e., it had higher antioxidant activity) in the high $\mathrm{CO}_{2}, 70 \% \mathrm{PAB}$ light conditions and nutrient enriched treatments (Table 3, Table S4).

\section{Discussion}

Recent reviews surmise that ocean acidification is likely to increase macroalgal productivity due to beneficial effects of increased dissolved inorganic carbon (DIC) levels which can stimulate the growth of algae and allows them to divert more resources into anti-herbivore and photo-protective compounds
(Harley et al., 2012; Brodie et al., 2014). Here we show that calcified and non-calcified macroalgae can indeed benefit physiologically from increases in DIC, but that the benefits, and the extent of the algal response, depend upon nutrient and light availability. Figure 6 summarizes our projections that brown macroalgal stands will both proliferate in the shallows (because of up-regulation of anti-herbivore and photo-protective compounds) and extend deeper due to a combination of ocean acidification and anthropogenic nutrient input, whereas other work on Mediterranean $\mathrm{CO}_{2}$ seeps has established that sea urchins and coralline algae are adversely affected by acidification (Baggini et al., 2014). In vivo chlorophyll a fluorescence parameters (maximal quantum yield or $F_{v} / F_{m}$ and maximal electron transport rate or $\mathrm{ETR}_{\max }$ ) and algal biochemical composition (Chla, total phenolic compounds and antioxidant activity, \%C) helps explain the dominance of phaeophytes at a variety of coastal Mediterranean $\mathrm{CO}_{2}$ seeps. Increases in brown macroalgal cover at $\mathrm{CO}_{2}$ seep sites are probably due to a combination of the direct stimulus of increased DIC for photosynthesis for species with inefficient carbon concentrating mechanisms (CCMs), and decreased grazing since sea urchins for example are excluded by hypercapnia (Calosi et al., 2013).

Other Mediterranean seep locations show similar trends to Vulcano, with increases in Cystoseira and Padina species at elevated $\mathrm{CO}_{2}$ locations compared to reference locations (Johnson et al., 2012; Baggini et al., 2014). Work in other regions has also shown that ocean acidification can directly benefit some macroalgae, such as Gracilaria lemaneiformis in China (Zou and Gao, 2009) and mat-forming Feldmannia spp. in Australia (Russell et al., 2011), as well as canopy-forming phaeophytes such as Nereocystis luetkeana and Macrocystis pyrifera (Swanson and Fox, 2007; Roleda et al., 2012). We found that the benefits of increased DIC were even more pronounced when combined with increased nutrients. This is what we expected, given that macroalgae tend to be nutrient-limited in oligotrophic waters such as those of the Mediterranean Sea (Ferreira et al., 2011). Both our study species increased electron transport rates and the accumulation of photoprotectors when exposed to a Nitrogen Phosphorus Potassium fertilizer, but these were short-term experiments with macroalgae grown in isolation. We suspect that chronic eutrophication combined with ocean acidification may benefit more opportunistic algal groups, to the detriment of brown macroalgae based on research by Russell et al. (2009) and Falkenberg et al. (2013). In our study, C. compressa and $P$. pavonica had increased carbon content at elevated $\mathrm{CO}_{2}$, which was augmented by increases in a range of other physiological parameters when nutrient levels were also increased. The $F_{v} / F_{m}$ ratio was highest at increased $\mathrm{CO}_{2}$ concentrations with no nutrient enrichment in $C$. compressa, but highest at increased $\mathrm{CO}_{2}$ with nutrient enrichment for $P$. pavonica (Figure 4). The maximal photosynthetic activity $\left(\mathrm{ETR}_{\max }\right)$ in $C$. compressa was reduced at high nutrient levels in shaded conditions but in fully lit conditions nutrients did not have significant effects under high DIC conditions. In other Cystoseira species, such as C. tamariscifolia, both $F_{v} / F_{m}$ and $\mathrm{ETR}_{\max }$ also decrease in nutrient enriched treatments in field experiments at various 


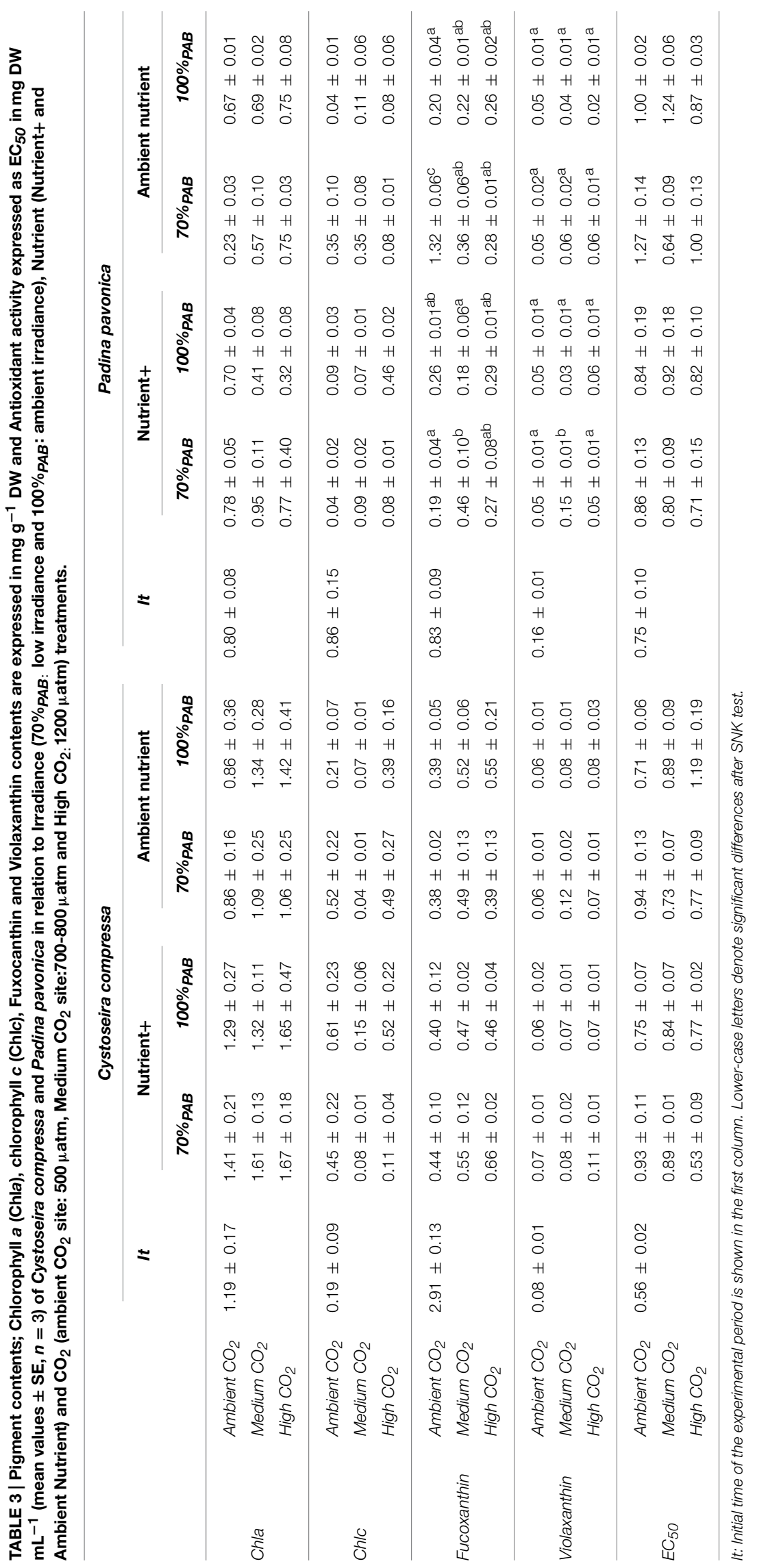




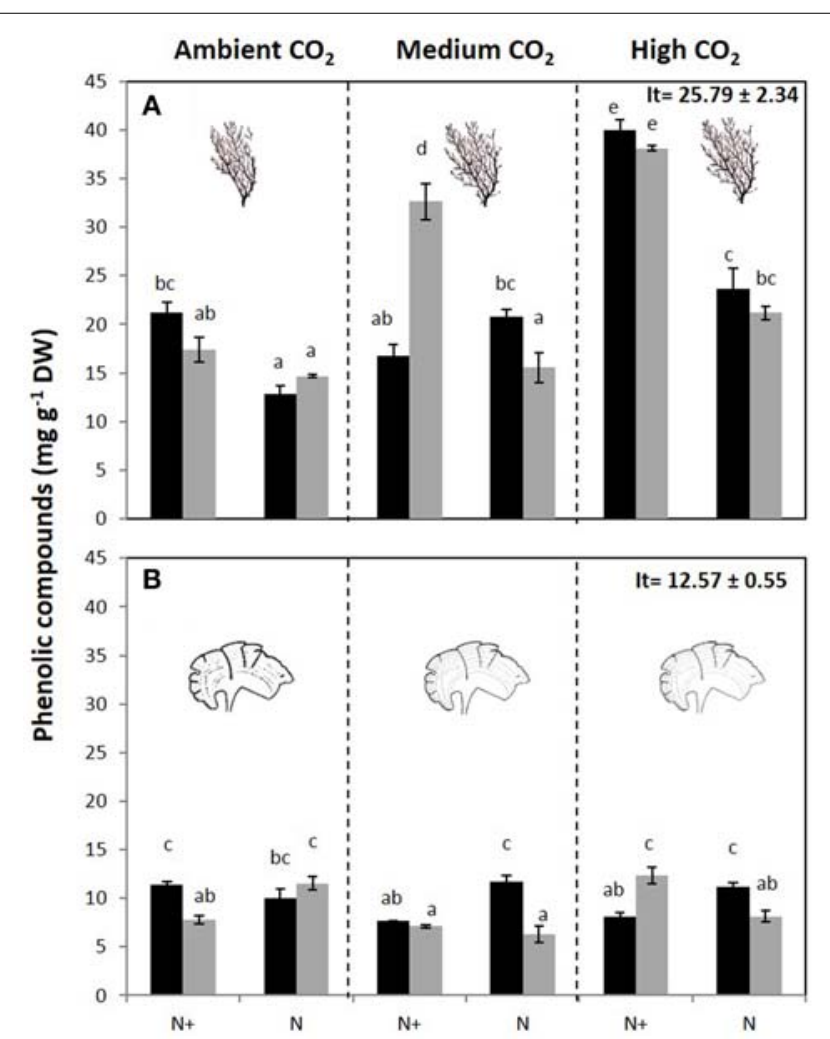

FIGURE 5 | Total phenolic compounds $\left(\mathrm{mg} \mathrm{g}^{-1} \mathrm{DW}\right)($ mean $\pm \mathrm{SE}, n=3)$ in (A) Cystoseira compressa and (B) Padina pavonica from Ambient $\mathrm{CO}_{2}$ (ca $500 \mu$ atm, left boxes), Medium $\mathrm{CO}_{2}$ (ca 700-800 $\mu$ atm, middle boxes) and High $\mathrm{CO}_{2}$ (ca $1200 \mu$ atm, right boxes), in Irradiance and Nutrient treatments. Dark bars indicate 70\% PAB (low irradiance), gray bars indicate 100\% and non-enriched treatments respectively. Upper values in right box indicate initial time values (It: mean $\pm \mathrm{SE}, n=3$ ). Lower-case letters denote significant differences after an SNK test.

depths (Celis-Plá et al., 2014a). In another experiment, Celis-Plá et al. (2014b) found the highest $\mathrm{ETR}_{\max }$ in C. tamariscifolia in thalli with the lowest internal nitrogen stores i.e., winter compared to summer grown algae. On the other hand, $\mathrm{Ek}_{\mathrm{NPQ}}$ increased in all cases with the increased $\mathrm{CO}_{2}$ as an acclimation to high light levels. On this basis, it is clear that the responses of coastal macroalgal communities to ocean acidification will depend on nutrient availability, and will be species-specific. Given these results we expect that in temperate waters, brown algae will benefit from increases in $\mathrm{CO}_{2}$ if sufficient nutrients are available (Johnson et al., 2012). However, as with all ecology, we can expect that there will be a region-specific balancing act. We show here that in oligotrophic conditions brown macroalgae were unable to take full advantage of increased inorganic carbon availability. There is added complexity when we consider that many regions have experienced a die-back of canopy-forming brown algae due to excess nutrients or sedimentation (Strain et al., 2014); ocean acidification may exacerbate this problem since increased DIC may further benefit those algae that presently compete with fucoids and kelps in eutrophic conditions (Connell et al., 2013).
Light quantity and quality drive physiological processes in macroalgae (Hanelt and López-Figueroa, 2012), so we were not surprised to find that shading affected their responses to ocean acidification. We anticipated two outcomes of the effects of light: we expected ETR rates to be higher as the most obvious response to light, but we also expected low-light macroalgae to increase ETR rates and $\% \mathrm{C}$ when transplanted to higher $\mathrm{CO}_{2}$ concentrations. Our first expectations were met, as maximum quantum yield, photosynthetic efficiency, irradiance of saturation and non-photochemical quenching for chlorophyll fluorescence all increased at higher light levels and were, at times, amplified by increasing $\mathrm{CO}_{2}$ and nutrient levels. The only instance where our second expectation was met was for $P$. pavonica under ambient nutrients, which had significantly higher \%C (and nonsignificantly higher $\mathrm{ETR}_{\max }$ ) when transplanted to elevated $\mathrm{CO}_{2}$ sites. Previous studies at the same sites found elevated $\mathrm{ETR}_{\max }$ when comparing $P$. pavonica at an elevated $\mathrm{CO}_{2}$ site compared to an ambient $\mathrm{CO}_{2}$ site (Johnson et al., 2012). If the duration of our experiment had been longer, our transplanted $P$. pavonica may also have significantly increased their $\mathrm{ETR}_{\max }$. Our results emphasize the likelihood that ocean acidification will act upon primary production differently at different latitudes and depths, not always according to our expectations. This is important since increases in land nutrient run-off, due to changes in land use and/or rainfall, are altering light levels in coastal waters (Scherner et al., 2013).

One of the most important photoprotective mechanisms available to algae is an ability to dissipate excess thermal energy (Adams et al., 2006). Thermal dissipation measured as non-photochemical PSII fluorescence quenching (NPQ) is triggered by the trans-thylakoidal proton gradient $(\Delta \mathrm{pH})$ and zeaxanthin (ZEA) synthesis through the xanthophyll cycle (Gilmore et al., 1994) and is recognized as the most important photoprotective mechanisms in higher plants and several algal divisions (Rodrigues et al., 2002). Fucoxanthin and violaxanthin levels were not affected in C. compressa whereas in $P$. pavonica fucoxanthin and violaxanthin increased under $70 \%$ PAB conditions, nutrient enrichment and medium $\mathrm{CO}_{2}$ levels. We used $\mathrm{NPQ}_{\max }$ as an indicator of photoprotective energy dissipation efficiency (Celis-Plá et al., 2014b), and we also measured phenolic content and antioxidant activity $\left(\mathrm{EC}_{50}\right)$, both of which can be used as photoprotectors (Celis-Plá et al., 2014a). In C. compressa and $P$. pavonica $\mathrm{NPQ}_{\max }$ was higher in all shaded treatments with nutrient enrichment, but not in the fully lit treatments, indicating higher photoprotection when nutrients were elevated and light was reduced. Phenols usually accumulated under higher irradiance and (for C. compressa) higher $\mathrm{CO}_{2}$ treatments, as per past studies on kelp grown at high $\mathrm{CO}_{2}$ (Swanson and Fox, 2007), or measured under higher irradiance (Connan et al., 2004). However, the effects of $\mathrm{CO}_{2}$ on autotroph phenol production are not straight forward, as previous work has shown that both seagrass (Arnold et al., 2012) and the macroalga Cystoseira tamariscifolia (Figueroa et al., 2014b) decrease phenol production when $\mathrm{CO}_{2}$ increased. In $C$. compressa and $P$. pavonica, antioxidant activity and $\mathrm{EC}_{50}$ were affected by the interactions between light levels and $\mathrm{CO}_{2} . \mathrm{EC}_{50}$ tended to be higher in shaded, high $\mathrm{CO}_{2}$ 

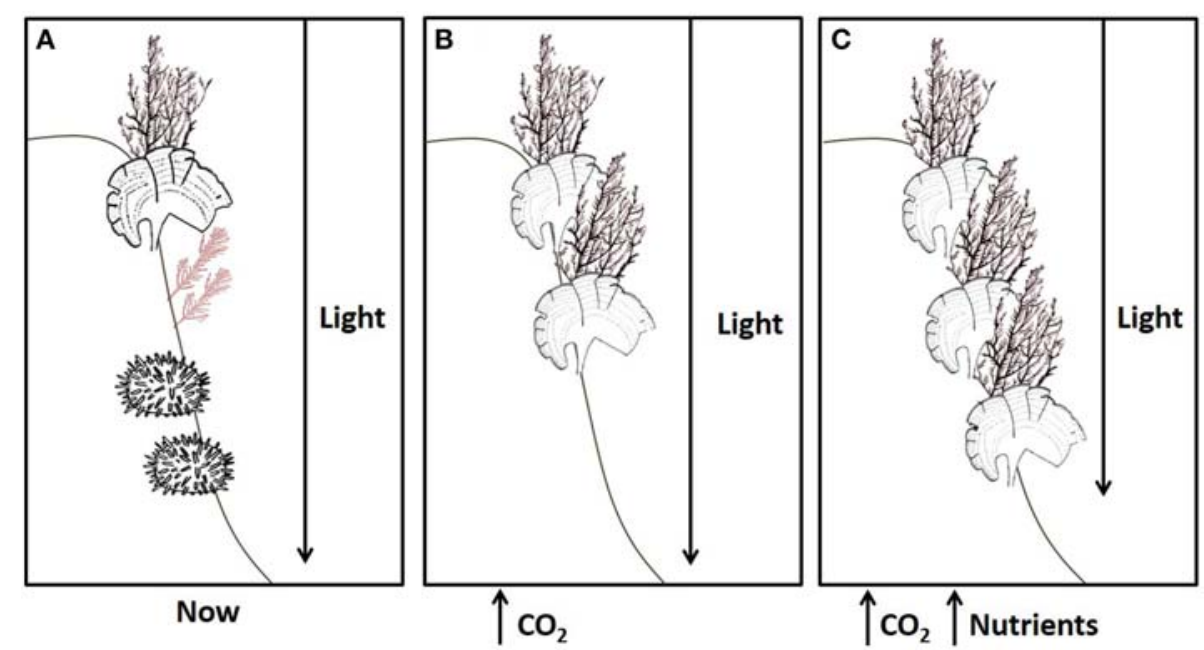

FIGURE 6 | The effects of ocean acidification on rocky shore communities will depend on nutrient levels. (A) A typical brown algal canopy with coralline algae and sea urchins at present-day levels of $\mathrm{CO}_{2}$, nutrients and light. (B) Increased $\mathrm{CO}_{2}$ in oligotrophic conditions has adverse impacts on most calcified organisms, such as coralline algae and sea urchins, yet dense brown algal stands persist at shallow depths despite corrosion of facultatively calcified algae, such as Padina. (C) Ocean acidification remains detrimental to most calcified organisms, but when this is combined with nutrient enrichment fleshy algae can flourish since they are able to take full advantage of increases in $\mathrm{CO}_{2}$, extending deeper into the photic zone despite increased turbidity. treatments with and without nutrient addition, suggesting a positive correlation with phenolic compounds and their use as antioxidants to prevent photodamage. Together, $\mathrm{NPQ}_{\max }$, phenol production and $\mathrm{EC}_{50}$ indicate that in elevated $\mathrm{CO}_{2}$ conditions some species will have a higher capacity for photoprotection.

Macroalgae regulate their biochemical composition to changes in solar radiation (Bischof et al., 2006; Figueroa et al., 2014a,b). Whilst light obviously affects photosynthesis, other variables such $\mathrm{pH}$, nutrients and the availability of different DIC species all have the potential to affect photosynthetic rates (Raven and Beardall, 2014). As interactions among such factors will determine the success of algal species and the amount of primary productivity in any time and place, it is crucial to know how the effects of ocean acidification are modified by other key drivers of photosynthesis. Research similar to our study, but with more species, in more locations and for longer durations, is clearly required before solid conclusions can be made with respect to the effects of ocean acidification on macroalgal productivity.

In conclusion, our study shows that ongoing ocean acidification can be expected to increase photosynthetic efficiency and algal productivity. The magnitude of these effects, and the species that benefit, will depend on light and nutrient levels. We show that $C$. compressa and $P$. pavonica are able to benefit from an increase in $\mathrm{CO}_{2}$ levels, rapidly changing their physiology and biochemical composition over 3 day alterations in DIC, irradiance and nutrients. These factors had interactive effects on photosynthetic and photoprotective systems in both species and help explain why brown algae proliferate at $\mathrm{CO}_{2}$ seeps. Longer-term growth studies involving algal interactions would be useful: we remain concerned that chronic eutrophication combined with ocean acidification may benefit more opportunistic algal groups to the detriment of canopy-forming brown macroalgae. As ocean acidification is not happening in isolation, but alongside a plethora of other anthropogenic changes, an understanding of the interactive effects of multiple stressors is critical to plan for global ocean change. We have shown that elevated $\mathrm{CO}_{2}$ levels can enhance brown algal productivity, and may boost the kelp and fucoid forests of the planet, but the effects will depend upon interactions with other physicochemical parameters such as light and nutrient availability.

\section{Acknowledgments}

This work was supported by the Junta de Andalucía (Project RNM-5750) and by the research group RNM-295. The NERC/Defra/DECC UK Ocean Acidification research programme and Save Our Seas Foundation contributed to fieldwork expenses (this video https://vimeo.com/101795615 shows the field site). PC gratefully acknowledges financial support from "Becas-Chile" (CONICYT) fellowship of doctorate of the Ministry of Education of the Republic of Chile. P. A. Horta is also grateful to CNPq grants, CAPES (PNADB/visitant professor fellowship) and INCT-MC to additional financial support.

\section{Supplementary Material}

The Supplementary Material for this article can be found online at: http://journal.frontiersin.org/article/10.3389/fmars. 2015.00026/abstract 


\section{References}

Adams, W. W. I. I. I., Zarter, C. R., Mueh, K. E., Amiard, V. S. E., and DemmigAdams, B. (2006). "Energy dissipation and photoinhibition: a continuum of photoprotection," in Photoprotection, Photoinhibition, Gene Regulation, and Environment, eds B. Demmig-Adams, W. W. III. Adams, A, Mattoo (Dordrecht: Springer), 49-64.

Aphalo, P. J., Albert, A., McLeod, A., Heikkilä, A., Gómez, I., Figueroa, F. L., et al. (2013). "2 Manipulating UV radiation," in Beyond the Visible A Handbook of Best Practice in Plant UV Photobiology, eds P. J. Aphalo, A. Albert, L. O. Björn, A. McLeod, T. M. Robson, and E. Rosenqvist (COST Action FA0906 UV4growth, Helsinki: University of Helsinki, Division of Plant Biology), 35-70.

Arnold, T., Mealey, C., Leahey, H., Miller, A. W., Hall-Spencer, J. M., Milazzo, M., et al. (2012). Ocean acidification and the loss of phenolic substances in marine plants. PLoS ONE 7:e35107. doi: 10.1371/journal.pone.0035107

Baggini, C., Salomidi, M., Voutsinas, E., Bray, L., Krasakopoulou, E., and HallSpencer, J. M. (2014). Seasonality affects macroalgal community response to increases in $p \mathrm{CO}_{2}$. PLoS ONE 9:e106520. doi: 10.1371/journal.pone.01 06520

Bermejo, R., De la Fuente, G., Vergara, J. J., and Hernández, I. (2013). Application of the CARLIT index along a biogeographical gradient in the Alboran Sea (European Coast). Mar. Pollut. Bull. 72, 107-118. doi: 10.1016/j.marpolbul.2013.04.011

Bischof, K., Gómez, I., Molis, M., Hanelt, D., Karsten, U., Lüder, U., et al. (2006). Ultraviolet radiation shapes seaweed communities. Rev. Environ. Sci. Biot. 5, 141-166. doi: 10.1007/s11157-006-0002-3

Blois, M. S. (1958). Antioxidant determinations by the use of a stable free radical. Nature 181, 1199-1200. doi: 10.1038/1811199a0

Boatta, F., D’Alessandro, W., Gagliano, A. L., Liotta, M., Milazzo, M., Rodolfo-Metalpa, R., et al. (2013). Geochemical survey of Levante Bay, Vulcano Island (Italy) and its suitability as a natural laboratory for the study of ocean acidification. Mar. Pollut. Bull. 73, 485-494. doi: 10.1016/j.marpolbul.2013.01.029

Brodie, J., Williamson, C., Smale, D. A., Kamenos, N. A., Mieszkowska, N., Santos, R., et al. (2014). The future of the northeast Atlantic benthic flora in a high $\mathrm{CO}_{2}$ world. Ecol. Evol. 4, 2787-2798. doi: 10.1002/ece3.1105

Calosi, P., Rastrick, S. P. S., Graziano, M., Thomas, S. C., Baggini, C., Carter, H. A., et al. (2013). Distribution of sea urchins living near shallow water $\mathrm{CO}_{2}$ vents is dependent upon species acid-base and ion-regulatory abilities. Mar. Poll. Bull. 73, 470-484 doi: 10.1016/j.marpolbul.2012.11.040

Celis-Plá, P. S. M., Korbee, N., Gómez-Garreta, A., and Figueroa, F. L. (2014b). Seasonal photoacclimation patterns in the intertidal macroalga Cystoseira tamariscifolia (Ochrophyta). Sci. Mar. 78, 377-388. doi: 10.3989/scimar.04053.05A

Celis-Plá, P. S. M., Martínez, B., Quintano, E., García-Sánchez, M., Pedersen, A., Navarro, N. P., et al. (2014a). Short-term ecophysiological and biochemical responses of Cystoseira tamariscifolia and Ellisolandia elongata to changes in solar irradiance and nutrient levels. Aquat. Biol. 22, 227-243. doi: 10.3354/ab00573

Connan, S., Goulard, F., Stiger, V., Deslandes, E., and Ar-Gall, E. (2004). Interspecific and temporal variation in phlorotannin levels in an assemblage of brown algae. Bot. Mar. 47, 410-416. doi: 10.1515/BOT.2004.057

Connell, S. D., Kroeker, K. J., Fabricius, K. E., Kline, D. I., and Russell, B. D. (2013). The other ocean acidification problem: $\mathrm{CO}_{2}$ as a resource among competitors for ecosystem dominance. Philos. Trans. R. Soc. Lond. B Biol. Sci. 368:20120442. doi: 10.1098/rstb.2012.0442

Cornwall, C. E., Revill, A. T., and Hurd, C. L. (2015). High prevalence of diffusive uptake of $\mathrm{CO}_{2}$ by macroalgae in a temperate subtidal ecosystem. Photosynth. Res. 124, 181-190. doi: 10.1007/s11120-015-0114-0

Dickson, A. G. (1990). Standard potential of the reaction: $\mathrm{AgCl}(\mathrm{s})+1 / 2 \mathrm{H}_{2}(\mathrm{~g})$ $=\mathrm{Ag}(\mathrm{s})+\mathrm{HCl}(\mathrm{aq})$, and the standard acidity constant of the ion $\mathrm{HSO}_{4}^{-}$in synthetic seawater from 273.15 to $318.15 \mathrm{KJ}$. J. Chem. Thermodyn. 22, 113-127. doi: 10.1016/0021-9614(90)90074-Z

Eilers, P. H. C., and Peeters, J. C. H. (1988). A model for the relationship between light intensity and the rate of photosynthesis in phytoplankton. Ecol. Model. 42, 199-215. doi: 10.1016/0304-3800(88)90057-9

Falkenberg, L. J., Connell, S. D., and Russell, B. D. (2013). Disrupting the effects of synergies between stressors: improved water quality dampens the effects of future $\mathrm{CO}_{2}$ on a marine habitat. J. Appl. Ecol. 50, 51-58. doi: 10.1111/13652664.12019

Ferreira, J. G., Andersen, J. H., Borja, A., Bricker, S. B., Camp, J., Cardoso da Silva, M., et al. (2011). Overview of eutrophication indicators to assess environmental status within the European Marine Strategy Framework Directive. Estuar. Coast. Shelf. S. 93, 117-131. doi: 10.1016/j.ecss.2011.03.014

Figueroa, F. L., Conde-Álvarez, R., and Gómez, I. (2003). Relations between electron transport rates determined by pulse amplitude modulated chlorophyll fluorescence and oxygen evolution in macroalgae under different light conditions. Photosynth. Res. 75, 259-275. doi: 10.1023/A:1023936313544

Figueroa, F. L., Dominguez-González, B., and Korbee, N. (2014a). Vulnerability and acclimation to increased UVB in the three intertidal macroalgae of different morpho-functional groups. Mar. Env. Res. 101, 8-21. doi: 10.1016/j.marenvres.2014.01.009

Figueroa, F. L., Malta, E.-J., Bonomi-Barufi, J., Conde-Álvarez, R., Nitschke, U., and Arenas, F. (2014b). Short-term effects of increasing $\mathrm{CO}_{2}$, nitrate and temperature on three Mediterranean macroalgae: biochemical composition. Aquat. Biol. 22, 177-193. doi: 10.3354/ab00610

García-Plazaola, J. I., and Becerril, J. M. (1999). A rapid HPLC method to measure lipophilic antioxidants in stressed plants: simultaneous determination of carotenoids and tocopherols. Phytochem. Anal. 10, 307-313.

García-Plazaola, J. I., Fernandez-Marin, B., and Porcar-Castell, A. (2012). Thermal energy dissipation and xanthophyll cycles beyond the Arabidopsis model. Photosynth. Res. 113, 89-103. doi: 10.1007/s11120-012-9760-7

Gaylord, B., Kroeker, K. J., Sunday, J. M., Anderson, K. M., Barry, J. P., Brown, N. E., et al. (2015). Ocean acidification through the lens of ecological theory. Ecology 96, 3-15. doi: 10.1890/14-0802.1

Gilmore, A. M., Mohanty, N., and Yamamoto, H. Y. (1994). Epoxidation of zeaxanthin and antheraxanthin reverses non-photochemical quenching of photosystem II chlorophyll a fluorescence in the presence of trans-thylakoid DpH. FEBS. Lett. 390, 271-274. doi: 10.1016/0014-5793(94)00784-5

Giordano, M., Beardall, J., and Raven, J. A. (2005). $\mathrm{CO}_{2}$ concentrating mechanisms in algae: mechanisms, environmental modulation, and evolution. Annu. Rev. Plant Biol. 56, 99-131. doi: 10.1146/annurev.arplant.56.032604.144052

Hanelt, D., and López-Figueroa, F. (2012). "Physiological and photomorphogenic effects of light of marine macrophytes," in Seaweed Biology Ecological Studies, eds C. Wienke and K. Bischof (Verlag: Springer), 3-23. doi: 10.1007/978-3-64228451-9_1

Harley, C. D. G., Anderson, K. M., Demes, K. W., Jorve, J. P., Kordas, R. L., and Coyle, T. A. (2012). Effects of climate change on global seaweed communities. J. Phycol. 48, 1064-1078. doi: 10.1111/j.1529-8817.2012.01224.x

Hepburn, C. D., Pritchard, D. W., Cornwall, C. E., Mcleod, R. J., Beardall, J., Raven, J. A., et al. (2011). Diversity of carbon use strategies in a kelp forest community: implications for a high $\mathrm{CO}_{2}$ ocean. Glob. Chan. Biol. 17, 2488-2497. doi: 10.1111/j.1365-2486.2011.02411.x

Hofmann, L. C., Heiden, J., Bischof, K., and Teichberg, M. (2014). Nutrient availability affects the response of the calcifying chlorophyte Halimeda opuntia (L.) J.V. Lamouroux to low pH. Planta 239, 231-242. doi: 10.1007/s00425-0131982-1

Hurd, C. L., Harrison, P. J., Bischof, K., and Lobban, C. S. (2014). Seaweed Ecology and Physiology, 2nd Edn. Cambridge: Cambridge University Press.

Johnson, V. R., Russell, B. D., Fabricius, K. E., Brownlee, C., and Hall-Spencer, J. M. (2012). Temperate and tropical brown macroalgae thrive, despite decalcification, along natural $\mathrm{CO}_{2}$ gradients. Glob. Chan. Biol. 18, 2792-2803. doi: 10.1111/j.1365-2486.2012.02716.x

Koch, M., Bowes, G., Ross, C., and Zhang, X. (2013). Climate change and ocean acidification effects on seagrasses and marine macroalgae. Glob. Chan. Biol. 19, 103-132. doi: 10.1111/j.1365-2486.2012.02791.x

Koroleff, F. (1983). "Determination of phosphorus," in Methods of Seawater Analysis: Second, revised and extended edition, eds K. Grasshoff, M. Ehrhardt, K. Kremling (Weinheim: Verlag Chemie), 125-139.

Martínez, B., Arenas, F., Rubal, M., Burgués, S., Esteban, R., García-Plazaola, I., et al. (2012). Physical factors driving intertidal macroalgae distribution: physiological stress of a dominant fucoid at its southern limit. Oecologia 170, 341-353. doi: 10.1007/s00442-012-2324-x

Oviedo, A. M., Ziveri, P., Álvarez, M., and Tanhua, T. (2015). Is coccolithophore distribution in the Mediterranean Sea related to seawater carbonate chemistry? Ocean Sci. Discuss. 11, 613-653. doi: 10.5194/osd-11-613-2014 
Pérez-Lloréns, J. L., Vergara, J. J., Pino, R. R., Hernandez, I., Peralta, G., and Niell, F. X. (1996). The effect of photoacclimation on the photosynthetic physiology of Ulva curvata and Ulva rotun data (Ulvales, Chlorophyta). Eur. J. Phycol. 31, 349-359. doi: 10.1080/09670269600 651581

Pettit, L. R., Smart, C. W., Hart, M. B., Milazzo, M., and Hall-Spencer, J. M. (2015). Seaweed fails to prevent ocean acidification impact on foraminifera along a shallow-water $\mathrm{CO}_{2}$ gradient. Ecol. Evol. 5, 1784-1793. doi: 10.1002/ece3.1475

Pierangelini, M., Stojkovic, S., Orr, P. T., and Beardall, J. (2014). Elevated $\mathrm{CO}_{2}$ causes changes in the photosynthetic apparatus of a toxic cyanobacterium, Cylindrospermopsis raciborskii. J. Plant Physiol. 171, 1091-1098. doi: 10.1016/j.jplph.2014.04.003

Pierrot, D. E., and Wallace, D. W. R. (2006). MS Excel Program Developed for $\mathrm{CO}_{2}$ System Calculations. ORNL/CDIAC-105a. Carbon Dioxide Information Analysis Center, Oak Ridge National Laboratory. Oak Ridge, TN: U.S. Department of Energy.

Porzio, L., Buia, M. C., and Hall-Spencer, J. M. (2011). Effects of ocean acidification on macroalgal communities. J. Exp. Mar. Biol. Ecol. 400, 278-287. doi: 10.1016/j.jembe.2011.02.011

Raven, J. A., and Beardall, J. (2014). $\mathrm{CO}_{2}$ concentrating mechanisms and environmental change. Aquat. Bot. 118, 24-37. doi: 10.1016/j.aquabot.2014. 05.008

Raven, J. A., Beardall, J., and Giordano, M. (2014). Energy costs of carbon dioxide concentrating mechanisms in aquatic organisms. Photosynth. Res. 121, 111-124. doi: 10.1007/s11120-0139962-7

Rodrigues, M. A., Dos Santos, C. P., Young, A. J., Strbac, D., and Hall, D. O. (2002). A smaller and impaired xanthophyll cycle makes the deep sea macroalgae Laminaria abyssalis (Phaeophyceae) highly sensitive to daylight when compared with shallow water Laminaria digitata. J. Phycol. 38, 939-947. doi: 10.1046/j.1529-8817.2002.t01-1-01231.x

Roleda, M. Y., Morris, J. N., McGraw, C. M., and Hurd, C. L. (2012). Ocean acidification and seaweed reproduction: increased $\mathrm{CO}_{2}$ ameliorates the negative effect of lowered $\mathrm{pH}$ on meiospore germination in the giant kelp Macrocystis pyrifera (Laminariales, Phaeophyceae). Glob. Chan. Biol. 18, 854-864. doi: 10.1111/j.1365-2486.2011. 02594.x

Roy, R. N., Roy, L. N., Vogel, K. M., Porter-Moore, C., Pearson, T., Good, C. E., et al. (1993). The dissociation constants of carbonic acid in seawater at salinities 5 to 45 and temperatures 0 to $45^{\circ}$ C. Mar. Chem. 4, 249-267. doi: 10.1016/0304-4203(93)90207-5
Russell, B. D., Pasasrelli, C. A., and Connell, S. D. (2011). Forecasted $\mathrm{CO}_{2}$ modifies the influence of light in shaping subtidal habitat. J. Phycol. 47, 744-752. doi: 10.1111/j.1529-8817.2011.01002.x

Russell, B. D., Thompson, J. I., Falkenberg, L. J., and Connell, S. D. (2009). Synergistic effects of climate change and local stressors: $\mathrm{CO}_{2}$ and nutrientdriven change in subtidal rocky habitats. Glob. Chan. Biol. 15, 2153-2162. doi: 10.1111/j.1365-2486.2009.01886.x

Scherner, F., Horta, P. A., Oliveira, E. C., Simonassi, J. C., Hall-Spencer, J. M., Chow, F., et al. (2013). Coastal urbanization leads to remarkable seaweed species loss and community shifts along the SW Atlantic. Mar. Poll. Bull. 76, 106-115. doi: 10.1016/j.marpolbul.2013.09.019

Schreiber, U., Endo, T., Mi, H., and Asada, K. (1995). Quenching analysis of chlorophyll fluorescence by the saturation pulse method: particular aspects relating to the study of eukaryotic algae and cyanobacteria. Plant Cell. Physiol. $36,873-882$.

Strain, E. M. A., Thomson, R. J., Micheli, F., Mancuso, F. P., and Airoldi, L. (2014). Identifying the interacting roles of stressors in driving the global loss of canopy-forming to mat-forming algae in marine ecosystems. Glob. Chan. Biol. 20, 3300-3312. doi: $10.1111 /$ gcb.12619

Swanson, A. K., and Fox, C. H. (2007). Altered kelp (Laminariales) phlorotannins and growth under elevated carbon dioxide and ultraviolet-B treatments can influence associated intertidal food webs. Glob. Chan. Biol. 13, 1696-1709. doi: $10.1111 / j .1365-2486.2007 .01384 . x$

Yesson, C., Bush, L. E., Davies, A. J., Maggs, C. A., and Brodie, J. (2015). Large brown seaweeds of the British Isles: evidence of changes in abundance over four decades. Estuar. Coast. Shelf. S. 155, 167-175. doi: 10.1016/j.ecss.2015.01.008

Zou, D., and Gao, K. (2009). Effects of elevated $\mathrm{CO}_{2}$ on the red seaweed Gracilaria lemaneiformis (Gigartinales, Rhodophyta) grown at different irradiance levels. Phycologia 48, 510-517. doi: 10.2216/08-99.1

Conflict of Interest Statement: The authors declare that the research was conducted in the absence of any commercial or financial relationships that could be construed as a potential conflict of interest.

Copyright (๐) 2015 Celis-Plá, Hall-Spencer, Horta, Milazzo, Korbee, Cornwall and Figueroa. This is an open-access article distributed under the terms of the Creative Commons Attribution License (CC BY). The use, distribution or reproduction in other forums is permitted, provided the original author(s) or licensor are credited and that the original publication in this journal is cited, in accordance with accepted academic practice. No use, distribution or reproduction is permitted which does not comply with these terms. 